\title{
Az Edzői Viselkedés Kérdőív hazai adaptációja
}

\author{
KOVÁCS KRISZTINA ${ }^{1,2^{*}}-$ KÖNIG-GÖRÖGH DÓRA ${ }^{3}-$ \\ F. FÖLDI RITA ${ }^{4}-$ GYÖMBÉR NOÉMI $^{1}$ \\ ${ }^{1}$ Testnevelési Egyetem, Gazdaság és Társadalomtudományi Intézet, Pszichológia \\ és Sportpszichológia Tanszék, Budapest, Magyarország \\ ${ }^{2}$ Budapest Honvéd Kosárlabda Akadémia, Budapest, Magyarország \\ ${ }^{3}$ Károli Gáspár Református Egyetem Tanítóképző Főiskolai Kar, \\ Budapest, Magyarország \\ ${ }^{4}$ Károli Gáspár Református Egyetem, Pszichológiai Intézet, Budapest, Magyarország
}

(Beérkezett: 2020. december 16.; elfogadva: 2021. május 7.)

Háttér és célkitüzések: Jelen tanulmány célja az Edzői Viselkedés Kérdőív (Coaching Behaviour Questionnaire) magyar változatának pszichometriai vizsgálata, a mérőeszköz reliabilitásának és validitásának ellenőrzése. Módszerek: A kérdőív érvényességét és megbízhatóságát egy 490 fős kényelmi mintán (234 férfi és 256 nő, átlagéletkor = 19,49 év; SD = 5,05 év) ellenőriztük. Az Edzői Viselkedés Kérdőív mellett felvételre került a Sportkörnyezet Kérdőív, a Sportmotiváció-2 Kérdőív, az Edző-Sportoló Kapcsolat Kérdőív, valamint a Sportverseny Pillanatnyi Szorongás Skála. Eredmények: A megerősítő faktoranalízis eredményeképpen az Edzői Viselkedés Kérdőív kétfaktoros elméleti modelljének illeszkedési mutatói megfelelónek bizonyultak $\left(\chi^{2}=386,36 ; d f=89\right.$; TLI = 0,90; CFI = 0,91; RMSEA = 0,08 [90\% CI = 0,07 - 0,09]; SRMR = 0,07). A kérdóív skáláinak belső megbízhatósága elfogadható (Negatív reakció Cronbach- $\alpha=0,87$, Támogatás Cronbach- $\alpha=0,87$ ). A konvergens validitás vizsgálata során a korábbi kutatásokkal megegyező korrelációkat kaptunk a Támogatás alskála és az észlelt autonómiatámogatás, az önbizalom, a sportmotiváció típusai és az edző-sportoló kapcsolat minősége között $(r=-0,29-0,90 ; p<0,001)$, a Negatív reakció alskála mindezeken a skálákon túl szignifikáns kapcsolatba hozható a sportolói állapotszorongással is $(r=0,21-0,25 ; p<0,001)$. Következtetések: Az Edzői Viselkedés Kérdőív magyarra fordított változata pszichometriailag megfelelő mérőeszköznek tekinthető.

Kulcsszavak: edző-sportoló kapcsolat, edzői viselkedés, edzői támogatás, negatív edzői viselkedés

\section{Bevezetés}

\subsection{Az edző-sportoló kapcsolat jellemzői}

A sportolói elégedettséget és önértékelést nagymértékben meghatározza az edző és a sportoló közötti kapcsolat minősége, amely a sportteljesítményre is jelentős hatást gyakorol (Gyömbér, Kovács, \& Ruzits, 2016). Az edző-

\footnotetext{
* Levelező szerző: Kovács Krisztina, Testnevelési Egyetem, Pszichológiai és Sportpszichológiai Tanszék, 1123 Budapest, Alkotás u. 44. E-mail: kovacs.krisztina@tf.hu
} 
sportoló kapcsolat vizsgálatának fó teoretikus hátterét Kelley és Thibaut (1978) interdependencia-elmélete adta, amely a személyek közötti kapcsolatot vizsgálja, annak költség-haszon viszonylatában. A társadalmi csereelmélet szerint a hatékony kapcsolatot a kiegyensúlyozottság jellemzi, azaz mindkét fél egyformán áldoz rá és profitál belőle. Az elmélet szerint az egyén olyan személyekkel alakít ki kapcsolatot, akik a legnagyobb jutalmat biztosítják és a legkisebb költséget jelentik számára. A sportban a megfelelő kapcsolat és együttmúködés az edző és a sportoló között nélkülözhetetlen az optimális múködés érdekében, valamint a sikeresség egyik alapköve. A sportolók csekély eséllyel érhetnek el kiemelkedő eredményt edzőjük útmutatása és támogatása nélkül, ahogy az edzők sem érhetik el a céljukat a tanítványaik kemény edzésmunkája és elkötelezettsége nélkül. A kölcsönös egymásrautaltság hatással lehet a diád együttmúködésének minőségére, alakíthatja a sportoló és edző sporttal kapcsolatos elégedettségének érzetét, amelynek része a teljesítménnyel kapcsolatos elégedettség, az instrukciók minősége és az egyénre szabott felkészítés (Jowett \& Nezlek, 2012).

Az edző-sportoló kapcsolat egy multidimenzionális konstruktumnak tekinthető, amely függ az adott helyzettől, valamint a közelség (closeness), az elkötelezettség (commitment) és a kiegészítés (complementarity) dimenziók mentén írható le a 3C modell (Jowett \& Ntoumanis, 2004) szerint. A közelség dimenziója jellemzi a kapcsolat affektív oldalát, és olyan érzelmekben nyilvánulhat meg, mint az egymás iránti bizalom, az elfogadás és a kötődés. Az elkötelezettség dimenzió a kognitív szempontokra koncentrál, amelyben az együttmúködéssel kapcsolatos elképzelések, tervek válnak hangsúlyossá. A kiegészítés pedig a viselkedéses megnyilvánulásokat helyezi a középpontba, úgymint az edzó és a tanítvány edzéseken és versenyeken mutatott cselekedetei. A közelség és elkötelezettség dimenziói tehát alapvetően az érzelmekről és a gondolatokról szólnak, a kiegészítés tekintetében pedig azt érdemes megvizsgálni, hogy az edző és a sportoló ezekkel összhangban cselekszenek-e. Megjegyzendő, hogy a 3C modell a kapcsolat minőségének meghatározása során nemcsak a sportoló (milyennek látja és értékeli az edzőjét - direkt nézőpont), hanem az edző szemszögét (mit gondol, milyennek látja őt a sportolója - meta nézőpont) is figyelembe veszi (Jowett, 2009, 2017). Jowett és Ntoumanis (2004) 3C modellje idővel kiegészült egy újabb dimenzióval, a koorientációval (coorientation), amely az edző és a sportoló közötti kapcsolat interdependenciáját jelzi (3C+1; Felton \& Jowett, 2015). A koorientáció két fél interakciójára és annak minőségére utal, azaz egy olyan platformot képvisel, ahol az edzók és a sportolók megoszthatják egymással a tapasztalataikat és élményeiket a kommunikáció csatornáin keresztül.

A 3C elméleti kerete alapján az egyéni különbségek, a szélesebb szociális kontextus (például normák) és a kapcsolat sajátosságai egyaránt hatással lehetnek az edző-sportoló kapcsolat minőségére (Jowett \& Poczwardowski, 
2007). Yang, Jowett és Chan (2015) kutatásuk során kapcsolatot találtak az edzó és a sportoló három személyiségvonása és az edző-sportoló kapcsolat pozitív minősége között: az extraverzióval negatív, míg az érzelmi stabilitással és a lelkiismeretességgel pozitív irányú kapcsolat mutatkozott. Továbbá az edző-sportoló kapcsolat minősége összefüggésbe hozható a sportoló elégedettségével (Felton \& Jowett, 2015) és motivációjával (Jowett és mtsai, 2017). Egy hazai kutatás eredménye szerint a sportoló elsajátítási céljai - azaz az új képesség tanulására és az erőfeszítésre irányuló motivációja - kapcsolatba hozhatók az edzók felől észlelt autonómiatámogatás mértékével (Kovács és mtsai, 2019). Az észlelt autonómiatámogatás a sportoló azon meggyőződése, amely az edzője olyan viselkedési mintáira vonatkozik, mint amilyen a kezdeményezókészség támogatása, a döntés lehetőségének biztosítása, a független problémamegoldás, a döntésekbe való bevonás, az érzések megosztása és elfogadása. Az észlelt autonómiatámogatás a sportoló öndeterminált motivációjának egyik alapköve (Mageau \& Vallerand, 2003). Úgy túnik továbbá, hogy egy edző korcsoportonként eltérő szerepet tölthet be a versenyzó életében (Révész és mtsai, 2013): míg a korai életkorokban az edző tanárként jelenik meg, a serdülőkor környékén az edzői szerepkörből fakadó motiváció kap kiemelt szerepet, a felnőtt korosztályban pedig megjelenik az edző mint barát szerepkör is, de egyben a teljesítményorientált hozzáállás is dominánssá válik, szemben a fiatalabb korosztályokkal.

Az edző-sportoló kapcsolat minősége hatással lehet arra, hogy mennyire elégedett a sportoló az edzésmunkájával (Yang és mtsai, 2015). Egy olimpiai érmet nyert versenyzók körében végzett kutatásban azt találták, hogy a sportolói eredményesség hátterében az edzó és a sportoló hatékony együttmúködése áll, amelynek kiemelt része az érzelmi közelség és a koorientáció (Jowett \& Cockerill, 2003). A nem megfelelő kapcsolat hatása is tetten érhető: evészavarral küzdő sportolók között jellemzőbb a bizonytalan kötődés az edzőjük irányába (Shanmugam, Jowett, \& Meyer, 2012).

\subsection{Az edzői viselkedés felmérése}

Smith és Smoll (1977) kutatásuk során edzői viselkedési formákat elemeztek, csoportosítottak és bontottak két nagyobb részre: spontán és reaktív viselkedésre. A reaktív viselkedés olyan azonnali válaszokat tartalmaz, amelyek a versenyző vagy a csapat egy adott viselkedését (kívánt cselekedetek, hiba vagy rossz minta) követik. A spontán viselkedést az edző kezdeményezi, amely során nem egy adott helyzetre reagál. Ezen belül két további alcsoport különíthetó el: a játékhoz kapcsolódó és nem kapcsolódó reakciók. Mindezek alapján a szerzők tizenkét viselkedési mintát azonosítottak, ame- 
lyek segítésével megfigyelhető és azonosítható az edzői múködésmód. Ez alapján született meg a Coaching Behavior Assessment System (CBAS; Edzői Viselkedés Értékelő Rendszer). Ez egy olyan értékelési szempontrendszer, amely az edző viselkedését elemzi mérkőzések és edzések alatt. A későbbiekben ennek a rendszernek köszönhetóen Smoll és Smith (1989) kialakítottak egy edzói vezetéselméleti modellt, amely a kognitív és affektív folyamatok mentén analizálja az edzői viselkedés sportolókra gyakorolt hatását. A vezetés kognitív-mediációs modellje (Cognitive-Mediational Model of Leadership) szerint az edző viselkedése helyzettől függően változhat, amit befolyásolhat a sportoló életkora, a verseny tétje, illetve a sportág specifikumai is. A sportolónak az edző viselkedésére adott reakciója is meghatározó lehet, hiszen az, ahogy a sportolók észlelik az edzőik viselkedését és magatartását, képes hatást gyakorolni az edzőikkel szembeni viszonyulásukra és a megélt sportélmény minőségére is. Az edzői viselkedés értelmezését tehát meghatározhatják a sportoló korábbi tapasztalatai az edzőjére és a helyzetre vonatkozóan, emellett az edzői viselkedés hatása nagymértékben függ az aktuálisan megjelenő szituatív tényezőktől és a sportolók által az ezen viselkedésnek tulajdonított jelentésétól.

A vezetés kognitív-mediációs modellje mentén született meg az Edzői Viselkedés Kérdőív (Coaching Behaviour Questionnaire, CBQ), amely kialakítása Kenow és Williams $(1992,1993,1999)$ munkásságához kötődik. Az első vizsgálati eredmények alapján e szerzők azt találták, hogy azok a sportolók, akik magas állapot- és vonásszorongással, valamint alacsony szintú önbizalommal jellemezhetók, negatívan értékelik az edzőjük viselkedését (Kenow \& Williams, 1992), valamint a kompatibilitás (azaz, hogy mennyire állnak összhangban a sportoló céljai, meggyőződései és személyisége az edzóével) és az állapotszorongás szignifikánsan előrejelzi azt, hogy hogyan jellemzik a sportolók az edzójüket (Kenow \& Williams, 1999). A 28 itemból álló CBQ kérdőív faktorstruktúráját Williams és munkatársai (2003) ellenőrizték. A feltáró faktoranalízis során a végső modell két- és háromfaktoros megoldása egyaránt megfelelőnek bizonyult, a megmaradt tételek (15 item) számottevő kereszttöltése nélkül. A megerősítő faktoranalízis során a kétfaktoros modell illeszkedési mutatói mutatkoztak jobbnak $\left(\chi^{2}(89)=164,28\right.$, $p<0,01 ; \mathrm{TLI}=0,92 ; \mathrm{RMSEA}=0,059 ; \mathrm{URFI}=0,93)$. A 15 itemből álló kérdőív két alskálájának megbízhatósága megfelelő volt (Negatív reakció alskála: Cronbach- $\alpha=0,82$ és Támogatás/megnyugtatás alskála: Cronbach- $\alpha=0,83$ ). A konstruktum validitás ellenőrzése során kosárlabda, röplabda és baseball sportágak összehasonlítása során a Negatív reakció alskála és a kognitív állapotszorongás ${ }^{1}$ (kosárlabda $r=0,30$; baseball $r=0,28$ ), illetve a szomatikus ál-

${ }^{1}$ Kognitív állapotszorongás: az adott pillanatra vonatkozó (a verseny előtt megélt) szorongás,
a verseny kimeneteléhez és a teljesítményhez kapcsolódó aggodalmak, negatív gondolatok. 
lapotszorongás ${ }^{2}$ (röplabda $r=0,34$ ) között pozitív, míg az önbizalom (kosárlabda $r=-0,20$; röplabda $r=-0,29$; baseball $r=-0,23$ ) és az edzó-sportoló közötti kompatibilitás (kosárlabda $r=-0,41$ ) között negatív irányú kapcsolatot találtak. A Támogatás/megnyugtatás alskála és az edző-sportoló közötti kompatibilitás (kosárlabda $r=-0,36$; röplabda $r=-0,59$ ), az önbizalom (röplabda $r=-0,28$ ), valamint a kognitív- (röplabda $r=-0,20$ ) és a szomatikus (röplabda $r=-0,22$ ) állapotszorongás között negatív kapcsolat mutatkozott (Williams és mtsai, 2003).

A CBQ kérdőívet fóként angolszász nyelvkörnyezetben használják, a szakirodalomban pedig csak görög nyelvi adaptációra történik utalás, ahol a kérdőív alskáláinak belsó megbízhatósága (Negatív reakció alskála: Cronbach- $\alpha=0,64$; Támogatás alskála: Cronbach- $\alpha=0,73)$, valamint a kétfaktoros elméleti modell illeszkedési mutatói $\left(\chi^{2}(89)=217,29, p<0,001\right.$; NFI $=0,83 ; \mathrm{NNFI}=0,88 ; \mathrm{CFI}=0,895 ;$ RMSEA = 0,061) elfogadhatónak bizonyultak (Karamousalidis és mtsai, 2010). Zourbanos és munkatársai (2010) CBQ kérdőívhez kapcsolódó kutatásának eredményei azt mutatták, hogy az edzővel való pozitív kapcsolat szignifikáns hatással van a sportoló belső beszédére (self-talk; pozitív belső beszéd: $r=0,42$, negatív belső beszéd: $r=$ -0,28), míg Mavridis és munkatársai (2019) a Támogatás/megnyugtatás alskála és az észlelt autonómia $(r=0,46)$, a kompetencia $(r=0,29)$ és a kötődés $(r=0,42)$ között szignifikáns, pozitív irányú kapcsolatot mutattak ki. Lee, Magnusen és Cho (2013) eredményei szerint női sportolók esetében az észlelt pozitív edzői viselkedés hatással volt az edző-sportoló kompatibilitás mértékére. Mindezekre a negatív edzői viselkedés nem volt hatással. A nemek közötti különbséget más vizsgálatban is kimutatták (Bebetsos, Filippou, \& Bebetsos, 2017): nagy tapasztalattal bíró, női versenysportolók edzóvel való kapcsolata inkább mutat pozitív képet, mint az ugyanilyen szinten versenyző férfiak kapcsolata az edzőjükkel.

A nemzetközi szakirodalom alapján célunk a CBQ hazai változatának elkészítése, hogy elsőként létrehozzunk és alkalmazhatóvá tegyünk a gyakorlat számára is egy olyan kérdőívet, amely megbízhatóan képes visszajelezni az edzői viselkedés pozitív és negatív aspektusait. Az edző-sportoló kapcsolat kiemelt szereppel bír a sportpszichológia területén, amely folyamatos kutatásra sarkallja a sportszakembereket. Jelen tanulmány célja, hogy ismertessük a méróeszköz pszichometriai jellemzőit. A konstruktum validitás ellenőrzésére a Sportkörnyezet Kérdőívet (SCQ-H; Kovács, Gyömbér, F. Földi, \& Lénárt, 2020), az Edző-Sportoló Kapcsolat Kérdőívet (CART-Q; Kovács, F. Földi, \& Gyömbér, 2021), valamint a Sportverseny Pillanatnyi

\footnotetext{
2 Szomatikus állapotszorongás: az adott pillanatra vonatkozó (a verseny elótt megélt) szorongás, stressz által kiváltott testi tünetek.
} 
Szorongás Skálát (CSAI-2, Sipos, Bejek, \& Kudar, 1999) vettük alapul, mivel a pszichológiai konstruktumok kapcsolatba hozhatók az edzői viselkedés formáival.

\section{Módszerek}

\subsection{Eljárás és adatfelvétel}

Az Edzői Viselkedés Kérdőív (CBQ) fordítását angolról magyarra két szakfordító végezte, majd a két változat összevetéséból és megvitatásából készült tételsort egy angol szakfordító fordította vissza az eredeti nyelvre. A visszafordítás ellenőrzését és jóváhagyását egy sportszakpszichológus szakfordító végezte. A kérdőívek magyar nyelvre fordítását a kérdőív jogtulajdonosa jogilag engedélyezte akadémiai kutatók részére.

Az adatfelvétel 2020. március és 2020. szeptember között zajlott le, egyetemi (Testnevelési Egyetem, Károli Gáspár Református Egyetem) hallgatók közremúködésével, különböző egyetemi kurzusok keretében. Az adatgyújtés kényelmi mintavételi eljárással történt: a hallgatók a szemináriumi munka részeként, általuk közvetlen vagy közvetett módon elért sportegyesületek, illetve szakképzett edzők segítségével jutottak el a vizsgálati személyekhez.

A felkeresett szövetségeket, egyesületeket és a részt vevő kiskorú sportolók szüleit és a sportolókat egyaránt tájékoztattuk a vizsgálat céljáról és a mérőeszközök tartalmáról. Utánpótlás korosztályok esetében szülői beleegyező nyilatkozatot kértünk. A kitöltés önkéntes és anonim módon történt, amit a résztvevők bármikor megszakíthattak és amelyért cserébe nem részesültek semmiféle kompenzációban, illetve az eredményeikről nem kaptak visszajelzést. A kérdőívet egy online felületen lehetett elérni (Google Ürlapok), kitöltése kb. 25-30 percet vett igénybe. A kutatást a Testnevelési Egyetem Kutatásetikai Bizottsága jóváhagyta, az etikai engedély száma: TE-KEB/No38/2019.

\subsection{Résztvevők}

Adatfelvételünket összesen 515 sportolóval végeztük el, majd adatredukciót követően 490 résztvevő adatait használtuk fel. A vizsgálatunkból kikerültek a 14 év alatti (7 fő) és a 40 év feletti (18 fő) sportolók. A kitöltők átlagéletkora 19,49 év (SD = 5,05 év; terjedelem: 14-39 év) volt. A válaszadók 40,2\%-a utánpótlás (18 év alatti), míg 46,7\%-a felnőtt korosztályba volt sorolható (64 fő nem jelölte meg az életkorát). A nemek megoszlása közel egyenlő volt: 234 férfi és 256 nő vett részt a kutatásunkban. 
A megkérdezettek 12 sportág képviselői voltak: 44,2\%-uk csapatsportágat (vízilabda 19,8\%, kézilabda 7,1\%, röplabda 6,1\%, kosárlabda 9,8\%, labdarúgás 1,4\%), 55,7\%-uk pedig egyéni sportágat (vívás 19,4\%, karate 18,8\%, ökölvívás 11,2\%, kajak-kenu 2,7\%, egyéb egyéni 3,4\%) úzött. A minta résztvevői átlagosan 8,85 éve sportoltak ( $\mathrm{SD}=5,05$ év; terjedelem: 1-34 év) és hetente átlagosan 10,02 órát (SD = 5,10 óra; terjedelem: 2-30 óra) töltöttek edzéssel. A megkérdezettek jelenlegi edzőjükkel átlagosan 4,05 éve dolgoznak együtt és jelenlegi pályafutásuk alatt átlagosan 4 edzőjük volt. A kitöltők mindössze 30,4\%-a dolgozik jelenleg is a nevelőedzőjével együtt. A megkérdezettek nagy része nemzetközi $(38,8 \%)$ vagy országos $(40,6 \%)$ szinten sportolt és kisebb részük sportolt helyi és hobbi szinten (8\%). A válaszadók mindössze 3,9\%-a nem versenyzett a kitöltés pillanatában, valamint $8,8 \%$ nem válaszolt a kérdésre.

\subsection{Mérőeszközök}

Az összeállított kérdőívcsomagban elsőként a sportolók demográfiai adataira (nem, életkor), valamint a sportággal és a sportolással kapcsolatos háttér-információkra (úgymint a sportág megnevezése, a heti edzésszám, az adott sportágban eltöltött évek száma, a versenyzés szintje, hány edzővel dolgozott együtt, és mióta edz a jelenlegi edzőjével) vonatkozó kérdések szerepeltek.

Edzői Viselkedés Kérdőív (Coaching Behavior Questionnaire, CBQ; Williams és mtsai, 2003): a kérdőív célja annak felmérése, hogy hogyan észlelik és értékelik a sportolók az edzőjük viselkedését. A 15 itemből álló kérdőív két alskálát foglal magába. A Negatív reakció alskála az edzők negatív viselkedését írja le, míg a Támogatás alskála az edzők pozitív viselkedését, reakcióit méri. A válaszokat négyfokú Likert-típusú skálán kell bejelölni az egyáltalán nem értek egyet (1) és a teljes mértékben egyetértek (4) végpontok között. A mérőeszköz nem tartalmaz fordított tételeket és a magasabb pontértékek az adott viselkedés nagyobb mértékét jelzik. A kérdőív megfelelő pszichometriai mutatókkal rendelkezik (Williams és mtsai, 2003; ld. fentebb).

Edzö-Sportoló Kapcsolat Kérdő́v (Coach-Athlete Relationship Questionnaire, CART-Q; Jowett \& Ntoumanis, 2004; magyar változat: Kovács és mtsai, 2021): a kérdőív az edző-sportoló kapcsolat affektív, kognitív és viselkedéses jellemzőit vizsgálja. A 11 kérdésból álló mérőeszköz nem tartalmaz fordított itemeket. Három alskálából áll: Közelség (érzelmi oldal), Elköteleződés (kogníció) és Kiegészítés (viselkedési oldal). A kitöltők hétfokú Likerttípusú skálán jelölhetik a válaszukat az egyáltalán nem értek egyet (1) és a teljes mértékben egyetértek (7) végpontok között. Az alskálákon elért maga- 
sabb pontszám az adott edző-sportoló kapcsolati minőség magasabb fokát jelzi. A kérdőív belső megbízhatósága a magyar adaptáció során megbízhatónak bizonyult (Cronbach- $\alpha=0,79-0,87$; Kovács és mtsai, 2021). Jelen mintán azonos értékeket kaptunk.

Sportkörnyezet Kérdőív (Sport Climate Questionnaire, SCQ-H; Deci, 2001; magyar változat: Kovács, Gyömbér, F. Földi, \& Lénárt, 2020): a kérdőív célja annak felmérése, hogy milyen mértékú autonómiát támogató viselkedést észlel a sportoló az edzóje felól. A kérdőív 12 itemből áll, nem tartalmaz fordított tételt. A kérdésekre a kitöltők hétfokú Likert-típusú skálán adják meg a választ az egyáltalán nem értek egyet (1) és a teljesen egyetértek (7) végpontok között. A magasabb pontértékek az autonómiatámogatás magasabb szintjét jelzik. A magyar adaptáció során a kérdőív belső megbízhatósága megfelelőnek bizonyult (Cronbach- $\alpha=0,94$; Kovács és mtsai, 2020). Jelen mintán azonos értéket kaptunk.

Sportverseny Pillanatnyi Szorongás Skála (Competitive State Anxiety Inventory-2, CSAI-2; Sipos és mtsai, 1999): a kérdőív a versenyhez kapcsolódó állapotszorongást vizsgálja. Három skálával rendelkezik: 1. a versenyzéssel kapcsolatos aktuális kognitív szorongásállapot (a versenyzéssel kapcsolatos kognitív szorongás), 2. a versenyzéssel kapcsolatos aktuális szomatikus szorongásállapot (szomatikus szorongás), és 3. a versenyzéssel kapcsolatos önbizalom. A kérdőív 27 kérdésból áll, alskálái 9 tételból tevődnek össze, a kérdésekre a kitöltők négyfokozatú Likert-típusú skálán adják meg a választ, az egyáltalán nem értek egyet (1) és a teljes mértékben egyetértek (4) végpontok között. A magasabb pontszámok magasabb szorongást és kedvezóbb versenyhelyzettel kapcsolatos önbizalmat jelentenek. Az alskálák belsó megbízhatósága a korábbi magyar kutatásokban megfelelőnek bizonyult. Géczi és munkatársai (2009) vizsgálatában a Cronbach- $\alpha$ értékek 0,72 és 0,84 között mozogtak, míg Kiss, Fózer-Selmeci, Csáki és Bognár (2015) kutatásában a 0,78 és 0,85 közötti tartományban helyezkedtek el. Jelen mintán a Cronbach- $\alpha$ értékek 0,77 és 0,83 között mozogtak.

Sportmotivációs Kérdőív (Sport Motivation Scale, SMS-II; Pelletier, Rocchi, Vallerand, Deci, \& Ryan, 2013; magyar változat: Smohai és mtsai, kézirat): a kérdőív az öndeterminációs elmélet keretein belül méri a sportolói motiváció mértékét és típusát. A 18 itemből álló kérdőívben a válaszadók egy hétfokú Likert-típusú skálán jelölhetik a válaszukat, az egyáltalán nem jellemző (1) és a nagyon jellemző (7) végpontok között. A kérdőív hat faktora az öndeterminált motiváció különböző szintjeit jellemzi. Az Amotiváció a szándék hiányáról szól. A nem öndeterminált motivációhoz sorolható a Külső szabályozás (külső hatás miatt) és az Introjektált szabályozás (kontrollált, a külső motiváció internalizálódik). Extrinzik, de már önmeghatározott jellegú motivációhoz tartozik az Identifikált motiváció (a személy szá- 
mára fontossá válik az adott dolog) és az Integrált motiváció (kongruencia, a késztetés összhangba kerül a személyiséggel). Végül az Intrinzik motivációt (az egyén az adott cselekedetet önmagáért végzi) egyértelmúen a belső szabályozás vezeti. A kérdőív hat skálájának összpontszámát a tételekre adott válaszok összegzése adja, a magasabb érték az adott motivációs típus magasabb szintjét jelzi. Az alskálák belsó megbízhatósága a hazai vizsgálatok során megfelelőnek bizonyult (Paic és mtsai, 2018: a Cronbach- $\alpha$ értékei 0,79-0,89 között; Smohai és mtsai, kézirat: a Cronbach- $\alpha$ értékei 0,62-0,80 között). Jelen vizsgálatban a Cronbach- $\alpha$ értékek 0,62 és 0,80 között mozogtak. Az extrinzik motivációnál megjelenó alacsonyabb értéket a szakirodalmi ajánlások mentén (Taber, 2018) elfogadhatónak tartjuk.

\subsection{Statisztikai elemzések}

Az Edzői Viselkedés Kérdőív magyar változatának (CBQ-H) faktorszerkezetét konfirmatív (megerősító) faktorelemzéssel teszteltük, amelyhez Williams és munkatársai (2003) kétfaktoros elméleti modelljét használtuk fel. A maximum likelihood becslési módszerrel végzett vizsgálatunk eredményeit több illeszkedési mutatóval is elemeztük, úgymint khí-négyzet $\left(\chi^{2}\right)$; a reziduumok átlagos négyzetgyöke (RMSEA - 0,08 alatti értéknél elfogadható); a Tucker-Lewis-index (TLI - jó illeszkedés 0,90 fölötti értéknél); komparatív illeszkedési mutató (CFI - jó illeszkedés 0,90 fölötti értéknél); sztenderdizált átlagos reziduális (SRMR - jó illeszkedés 0,80 alatti értéknél). Az illeszkedési mutatók elfogadható értékeivel kapcsolatban követtük a szakirodalom ajánlásait (Hu \& Bentler, 1999).

Megvizsgáltuk az Edzői Viselkedés Kérdőív megbízhatósági mutatóit is, amellyel kapcsolatban Cronbach- $\alpha$ mutatót (0,70-től elfogadható érték), továbbá a megmagyarázott variancia értékét (average variance explained; AVE - 0,70-tól elfogadható érték), és az indikátorhoz tartozó fogalmi megbízhatósági mutatót (composite reliablitity; CR - 0,70-től elfogadható érték) használtuk (Hair, Black, Babin, Anderson, \& Tatham, 1998).

A konvergens validitás vizsgálatához Pearson-féle product-moment korrelációs elemzéssel teszteltük a CBQ-H alskálái és az edző észlelt autonómiatámogatásának mértékét vizsgáló SCQ-H kérdőív, Sportverseny Pillanatnyi Szorongás Skála és a Sportmotivációs Kérdőív alskálái közötti kapcsolatot. A korrelációs együtthatók értelmezése során Cohen (1988) felosztását vettük alapul. Eszerint az együttható 0,3 alatti értéke gyenge, 0,3-0,5 közötti értéke közepes, 0,5 feletti értéke pedig erős kapcsolatot jelöl. Az adatok statisztikai elemzését az IBM SPSS Statistics for Windows, Version 22.0. és az IBM SPSS Amos, Version 24.0 programokkal végeztük. 


\section{Eredmények}

\subsection{Az Edzői Viselkedés Kérdőív faktorszerkezete}

Első lépésként az CBQ-H faktorstruktúrája került ellenőrzésre megerősítő faktorelemzés végrehajtásával, az eredeti kétfaktoros modellt tesztelve a mintán. Az elemzés eredménye megerősítette, hogy a kérdőív itemei - az elméleti modellnek megfelelően - két faktorba rendeződnek magyar mintán is (1. ábra). A teljes mintára nézve az illeszkedési mutatók elérték a minimálisan elvárt értékeket. Almintánként nemre (férfi és nő), korosztályra (utánpótlás és felnőtt korosztály) és sportági csoportosításra (egyéni és csapatsportolók) vonatkozóan elfogadható illeszkedési mutatókat kaptunk a nők és az egyéni sportolók almintájában, míg a férfiak csoportjában, a csapatsportolók között és a korosztályi bontásban több illeszkedési mutató értéke sem érte el a kívánt szintet (1. táblázat).

1. táblázat. Az Edzői Viselkedés Kérdőív konfirmatív faktoranalízisével kapott illeszkedési mutatók a teljes mintán és almintákra lebontva

\begin{tabular}{|l|c|c|c|c|c|c|c|c|c|}
\hline & $n$ & $p$ & $\chi^{2}$ & DF & TLI & CFI & RMSEA & $\begin{array}{c}\text { RMSEA } \\
\text { 90\% CI }\end{array}$ & SRMR \\
\hline Teljes minta & 490 & $<0,001$ & 386,36 & 89 & 0,90 & 0,91 & 0,08 & $0,07-0,09$ & 0,07 \\
\hline Nók & 256 & $<0,001$ & 226,27 & 89 & 0,92 & 0,93 & 0,08 & $0,06-0,09$ & 0,07 \\
\hline Férfiak & 234 & $<0,001$ & 309,49 & 89 & 0,81 & 0,84 & 0,10 & $0,09-0,11$ & 0,10 \\
\hline Egyéni & 255 & $<0,001$ & 223,94 & 89 & 0,92 & 0,93 & 0,08 & $0,06-0,09$ & 0,07 \\
\hline Csapat & 218 & $<0,001$ & 249,17 & 89 & 0,89 & 0,91 & 0,09 & $0,08-0,10$ & 0,07 \\
\hline $\begin{array}{l}\text { 14-18 év } \\
\text { (Utánpótlás) }\end{array}$ & 265 & $<0,001$ & 276,28 & 89 & 0,86 & 0,89 & 0,09 & $0,08-0,10$ & 0,08 \\
\hline $\begin{array}{l}\text { 19-39 év } \\
\text { (Felnótt) }\end{array}$ & 161 & $<0,001$ & 226,68 & 89 & 0,89 & 0,90 & 0,09 & $0,08-0,11$ & 0,08 \\
\hline
\end{tabular}




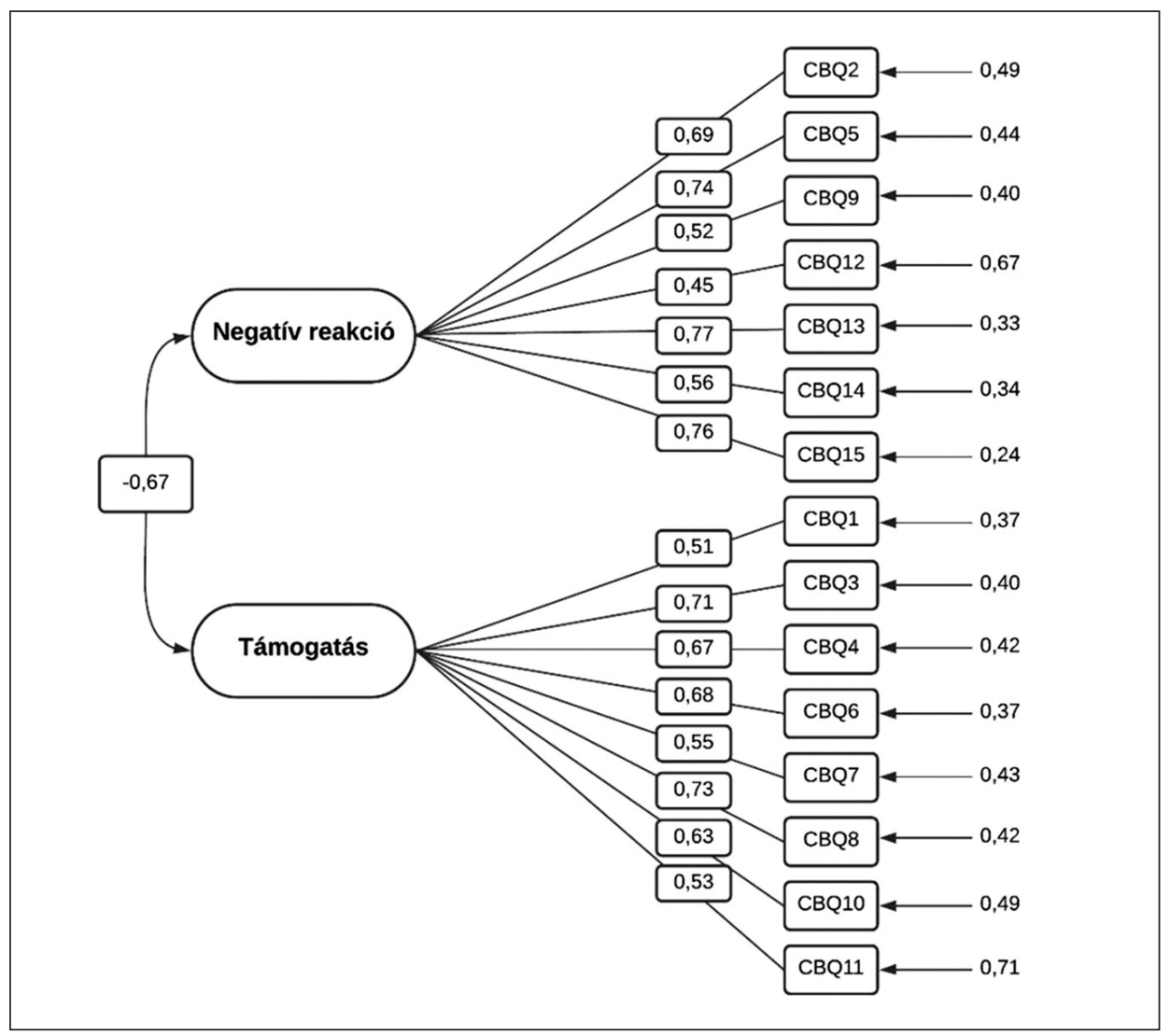

1. ábra. Az Edzői Viselkedés Kérdőív konfirmatív faktorelemzésének eredménye Megjegyzés: teljes minta $(n=490)$.

\subsection{Az Edzői Viselkedés Kérdőív reliabilitása}

Elemzésünkben a skála belső megbízhatóságának ellenőrzésére az ún. átlagos megmagyarázott variancia értékét $(A V E)$, az indikátorhoz tartozó fogalmi megbízhatósági mutatót $(C R)$, valamint Cronbach- $\alpha$-mutatót számoltunk, a teljes mintán (2. táblázat). A kapott Cronbach- $\alpha$ és CR megbízhatósági értékek megfelelőnek bizonyultak, de az AVE értéke minden esetben alacsonyabb, mint a referenciaérték. Fornell és Larcker (1981) ajánlása szerint, ha az AVE értéke alacsonyabb, mint 0,5, de a CR értéke nagyobb, mint 0,6, akkor a skálák megbízhatósága adekvátnak tekinthető, ezért úgy látjuk, hogy a 15 tételes és 2 faktoros szerkezet alkalmas az edzői viselkedés jellemzésére. 
2. táblázat. Az Edzői Viselkedés Kérdőív megbízhatósági mutatói a teljes mintán

\begin{tabular}{|l|l|c|c|c|c|c|}
\hline \multicolumn{1}{|c|}{ Minta } & \multicolumn{1}{|c|}{ Faktorok } & M & SD & Cronbach- $\alpha$ & AVE & CR \\
\hline $\begin{array}{l}\text { Teljes minta } \\
(n=490)\end{array}$ & Negatív reakció & 11,79 & 4,78 & 0,87 & 0,42 & 0,83 \\
\cline { 2 - 7 } & Támogatás & 24,62 & 5,37 & 0,87 & 0,40 & 0,84 \\
\hline
\end{tabular}

\subsection{Az Edzői Viselkedés Kérdőív validitása}

A CBQ-H alskálái és az észlelt edzói autonómiatámogatás, a sportmotiváció, az állapotszorongás, önbizalom, valamint az edző-sportoló kapcsolat minősége közötti kapcsolatot Pearson-féle korrelációs vizsgálattal elemeztük.

Szignifikáns, pozitív irányú, erős kapcsolatot találtunk a CBQ-H kérdőív Támogatás alskálája és az észlelt autonómiatámogatás mértéke, valamint az edző-sportoló kapcsolat pozitív aspektusai (kiegészítés, elköteleződés, közelség) között. Ugyancsak szignifikáns, pozitív irányú, gyenge, illetve közepes erősségú kapcsolatot mutattunk ki a támogatás és az identifikált, az integrált és az intrinzik szabályozás, valamint az önbizalom között. A fentieken túl szignifikáns, negatív irányú, gyenge kapcsolat mutatkozik az amotivációval (3. táblázat).

Szignifikáns, negatív irányú, közepes erősségú kapcsolatot találtunk a CBQ-H kérdőív Negatív reakció alskálája és az észlelt autonómiatámogatás mértéke között. A negatív reakció emellett szignifikáns, negatív irányú, közepes, illetve erős kapcsolatot mutatott az edző-sportoló kapcsolat pozitív aspektusaival. Az identifikált, az integrált és az intrinzik motiváció, valamint az önbizalom ugyancsak szignifikáns, negatív irányú, gyenge, illetve közepes erősségú kapcsolatban állt a negatív reakcióval. A fentieken túl szignifikáns, pozitív irányú, gyenge kapcsolat mutatkozott a negatív reakció és az amotiváció, a kognitív és a szomatikus állapotszorongás és a külső szabályozás között (3. táblázat). 
3. táblázat. Az Edzői Viselkedés Kérdőív magyar változata konstruktum validitásának ellenórzése

\begin{tabular}{|l|l|c|c|}
\hline \multirow{2}{*}{ Kérdőívek } & \multicolumn{2}{c|}{ Edzői Viselkedés Kérdőív } \\
\cline { 2 - 4 } & Negatív reakció & Támogatás \\
\hline SCQ Észlelt edzői autonómiatámogatás & $-0,41^{* *}$ & $0,70^{* *}$ \\
\hline \multirow{5}{*}{ SMS-II } & Amotiváció & $0,29^{* *}$ & $-0,29^{* *}$ \\
\cline { 2 - 4 } & Külsó Szabályozás & $0,16^{* *}$ & $-0,10$ \\
\cline { 2 - 4 } & Introjektált szabályozás & 0,01 & 0,04 \\
\cline { 2 - 4 } & Identifikált szabályozás & $-0,23^{* *}$ & $0,23^{* *}$ \\
\cline { 2 - 4 } & Integrált szabályozás & $-0,29^{* *}$ & $0,38^{* *}$ \\
\cline { 2 - 4 } & Intrinzik szabályozás & $-0,40^{* *}$ & $0,44^{* *}$ \\
\hline \multirow{5}{*}{ CSAI-2 } & Kognitív szorongás & $0,21^{* *}$ & $-0,02$ \\
\cline { 2 - 4 } & Szomatikus szorongás & $0,25^{* *}$ & $-0,05$ \\
\cline { 2 - 4 } & Önbizalom & $-0,31^{* *}$ & $0,21^{* *}$ \\
\hline \multirow{5}{*}{ CART-Q } & Kiegészítés & $-0,53^{* *}$ & $0,61^{* *}$ \\
\cline { 2 - 4 } & Elköteleződés & $-0,49^{* *}$ & $0,59^{* *}$ \\
\cline { 2 - 4 } & Közelség & $-0,55^{* *}$ & $0,63^{* *}$ \\
\hline
\end{tabular}

Megjegyzés: SCQ = Sportkörnyezet Kérdőív, SMS-II = Sportmotivációs Kérdőív, CSAI-2 = Sportverseny Pillanatnyi Szorongás Skála, CART-Q = Edző-Sportoló Kapcsolat Kérdőív. ** $p<0,001$.

\section{Megbeszélés}

Jelen tanulmány célja a Coaching Behavior Questionnaire (CBQ; Williams és mtsai, 2003) magyar nyelvú adaptációja, hogy így elérhetővé tegyük a hazai szakemberek számára is a nemzetközileg széles körben használt, jó pszichometriai mutatókkal rendelkező kérdőívet. Bár az eredeti kérdőív elemzése során Williams és munkatársai (2003) mind a két-, mind pedig a háromfaktoros megoldást megfelelőnek találták a feltáró faktoranalízis eredményeinek ellenőrzésekor, a megerősítő faktoranalízis eredménye kétfaktoros megoldást mutatott - azaz az edzői viselkedés leírható annak negatív és pozitív aspektusából is. 
A jelen vizsgálatban az Edzői Viselkedés Kérdőív magyar nyelvú változatának (CBQ-H) megerősítő faktorelemzése során a kétdimenziós modell illeszkedési mutatói elfogadhatónak bizonyultak a teljes mintára vonatkozóan. Míg a nők csoportjában és az egyéni sportolók között a kérdőív elméleti struktúrájának illeszkedése ugyancsak elfogadhatónak bizonyult, addig a korosztályok szerinti bontásban, a csapatsportolók között, valamint a férfiak mintájában az illeszkedési mutatók több esetben nem értek el elfogadható értékhatárt. A vizsgálatunkban a sportágak nem reprezentálták kelló elemszámmal magukat, emiatt az eredmények torzulhattak, továbbá az almintákra vonatkozó alacsony mintaelemszám okozta korlátok is vezethettek az illeszkedési mutatók nem megfelelő eredményeihez. Éppen ezért további vizsgálatok szükségesek annak megállapítására, hogy az alminták tekintetében milyen tulajdonságokkal bír a kérdőív.

Eredményeink alapján a CBQ-H kérdőív alskáláinak belső megbízhatóságára utaló két mérószám megfelelónek bizonyult a teljes mintán, azonban az AVE értéke elmarad a referenciaértéktől. A másik két megbízhatósági mutató ugyanakkor megfelelőnek bizonyult, így Fornell és Larcker (1981) ajánlása szerint az alskálák belső konzisztenciáját elfogadhatónak tekinthetjük.

A konstruktum validitás ellenőrzése során a szakirodalommal megegyező eredményeket kaptunk. Közepes mértékú, illetve erős (a Támogatás alskálával pozitív, míg a Negatív reakcióval negatív irányú) kapcsolatot találtunk a kérdőív alskálái, valamint az edző-sportoló kapcsolat minőségét elemző kérdőív (Jowett \& Ntoumanis, 2004) alskálái között. Ezek az eredmények további lehetőséget biztosítanak arra, hogy pontosabban feltárjuk a sportolók edzőikről kialakított képét, pozitív és negatív aspektusból egyaránt. Az észlelt autonómiatámogatás mértéke és a Támogatás alskála között pozitív irányú erős, míg a Negatív reakció közt negatív irányú, közepes erősségú kapcsolatot találtunk. Az autonómiát támogató edzői viselkedés előrejelzi a sportoló által észlelt pozitív edző-sportoló kapcsolatot (Felton \& Jowett, 2015; Lafrenière és mtsai, 2011), valamint az edzés sikerességét (Grant, 2013) egyaránt.

Vizsgálatunkban a sportolók öndeterminált jellegú motivációja is pozitív irányú, közepes erősségú kapcsolatot mutatott az edzői viselkedés támogató oldalával, míg negatív irányú közepes erősségú kapcsolatot az edzői viselkedés negatív megnyilvánulásaival. Mageau és Vallerand (2003) eredményei szerint az edzők viselkedése, múködés- és bánásmódja hatással van a versenyzők kompetenciaérzésére és autonómiájára, ezáltal pedig a motivációjukra is. Jowett és munkatársai (2017) pedig azt találták, hogy 
azok a sportolók, akik az edzőjükkel való kapcsolatukat pozitívan jellemzik, magasabb szintú elégedettségról számolnak be, amely pozitív módon jelzi előre a motivációjuk minőségét, és mindez kapcsolatba hozható a mentális jóllétükkel. Egy birkózók között végzett vizsgálat eredményei szerint az edző támogató viselkedése nemcsak a sportolói énhatékonyságot magyarázhatja, hanem előre jelezheti az intrinzik motivációjukat is (Sarı \& Bayazit, 2017).

A vizsgálatunk eredményei szerint a negatív edzői viselkedés kapcsolatba hozható a kognitív és szomatikus állapotszorongás mértékével, amely egybecseng Kenow és Williams $(1992,1993,1999)$ eredményeivel. Davis és Jowett (2014) érvelése szerint a rossz minőségú interperszonális kapcsolat szorongáshoz vezethet. Ledochowski és munkatársai (2012) eredményei szerint a megfelelő edzői viselkedés csökkentheti a sportolói teljesítményszorongás mértékét. Egy további kutatásban (Baker és mtsai, 2000) pedig azt találták, hogy a negatív edzői viselkedés magával vonhatja a sportolói állapotszorongás különböző megnyilvánulásait (szomatikus és kognitív szorongás, koncentrációs zavarok). A pozitív edzói viselkedés ezzel szemben fejlesztheti a sportoló önbizalmát (Solomon, 2008). Akárcsak az eredeti CBQ kérdőív validálása során (Williams és mtsai, 2003), a mi eredményeink is alátámasztották a kapcsolatot a pozitív és negatív edzői viselkedés, valamint a versenyzéssel kapcsolatos önbizalom között.

Az önkitöltős kérdőívek sajátosságai miatt fontos megemlíteni a kutatás limitációjaként a szociális megfelelési torzítás hatását, így a jövőben érdemes lehet a vizsgálatot egy ezt mérő skálával kiegészíteni. A vizsgálat további korlátja, hogy a CBQ-H kérdőív időbeli stabilitása nem került ellenơrzésre - ezt a későbbiekben érdemes lenne pótolni -, illetve, hogy egyes almintákban az illeszkedési mutatók bizonyultak nem megfelelőnek. Végül a különféle sportágak alulreprezentáltak voltak, ennek következtében az alminták nem tekinthetók reprezentatívnak, amely hatással lehetett az illeszkedési mutatók alakulására.

A későbbiek során fontos lenne megvizsgálni a kérdőív azon sajátosságait is, hogy milyen hatással bír az edzői viselkedés minőségére például a sportoló neme, az életkora, illetve maga a sportág.

Összeségében elmondható, hogy a kérdőív általános sportolói mintán megbízhatónak és érvényesnek bizonyult, így az Edzői Viselkedés Kérdőív magyar változata tovább gazdagítja az alkalmazott sportpszichológia gyakorlati szegmensét, és hozzájárulhat az edző-sportoló kapcsolat hatékonyabb megértéséhez és fejlesztéséhez. 


\section{Irodalom}

Baker, J., Côté, J., \& Hawes, R. (2000). The relationship between coaching behaviours and sport anxiety in athletes. Journal of Science and Medicine in Sport, 3(2), 110-119.

Bebetsos, E., Filippou, F., \& Bebetsos, G. (2017). Athletes' criticism of coaching behavior: differences among gender, and type of sport. Polish Psychological Bulletin, 25(1), 55-67.

Cohen, J. (1988). Statistical power analysis for the behavioral sciences (2nd ed.). New Jersey: Lawrence Erlbaum

Davis, L., \& Jowett, S. (2014). Coach-athlete attachment and the quality of the coach-athlete relationship: implications for athlete's well-being. Journal of Sports Sciences, 32(15), 14541464.

Deci, E. L. (2001). The sport climate questionnaire. Letöltve: 2019. 10. 08-án: http://self determinationtheory.org/pas-sport-climate/

Deci, E. L., \& Ryan, R.M. (2000). The "what" and "why" of goal pursuits: Human needs and the self-determination of behavior. Psychological Inquiry, 11(4), 227-268.

Felton, L., \& Jowett, S. (2015). On understanding the role of need thwarting in the association between athlete attachment and well/ill-being. Scandinavian Journal of Medicine $\&$ Science in Sports, 25(2), 289-298.

Fornell, C., \& Larcker, D.F. (1981). Evaluating structural equation models with unobservable variables and measurement error. Journal of Marketing Research, 18(1), 39-50.

Géczi, G., Tóth, L., Sipos, K., Fügedi, B., Dancs, H., \& Bognár, J. (2009). Psychological profile of Hungarian national young ice hockey players. Kinesiology, 41(1), 88-96.

Grant, A. M. (2014). Autonomy support, relationship satisfaction and goal focus in the coach-coachee relationship: which best predicts coaching success? Coaching: An International Journal of Theory, Research and Practice, 7(1), 18-38.

Gyömbér, N., Kovács, K., \& Ruzits, É. (2016). Gyereklélek sportcipóben. Budapest: Noran Libro Kiadó

Hair, J. F., Black, W. C., Babin, B. J., Anderson, R. E., \& Tatham, R. L. (1998). Multivariate data analysis. Upper Saddle River, NJ: Prentice Hall

Hu, L., \& Bentler, P M. (1999). Cut-off criteria for indexes in covariance structure analysis: conventional criteria versus new alternatives. Structural Equation Modelling, 6(1), $1-55$.

Jowett, S. (2009). Validating coach-athlete relationship measures with the nomological network. Measurement in Physical Education and Exercise Science, 13(1), 34-51.

Jowett, S. (2017). Coaching effectiveness: The coach-athlete relationship at its heart. Current Opinion in Psychology, 16, 154-158.

Jowett, S., \& Cockerill, I. M. (2003). Olympic medallists' perspective of the athlete-coach relationship. Psychology of Sport and Exercise, 4(4), 313-331.

Jowett, S., \& Meek, G.A. (2000). The coach-athlete relationship in married couples: An exploratory content analysis. The Sport Psychologist, 14(2), 157-175.

Jowett, S., \& Nezlek, J. (2012). Relationship interdependence and satisfaction with important outcomes in coach-athlete dyads. Journal of Social and Personal Relationships, 29(3), 287301.

Jowett, S., \& Ntoumanis, N. (2004). The coach-athlete relationship questionnaire (CART-Q): Development and initial validation. Scandinavian Journal of Medicine and Science in Sports, 14(4), 245-257.

Jowett, S., \& Poczwardowski, A. (2007). Understanding the Coach-Athlete Relationship. In S. Jowett, \& D. Lavallee (Eds.), Social psychology in sport (3-14). Champaign: Human Kinetics 
Jowett, S., Adie, J.W., Bartholomew, K. J., Yang, S. X., Gustafsson, H., \& Lopez-Jiménez, A. (2017). Motivational processes in the coach-athlete relationship: A multi-cultural selfdetermination approach. Psychology of Sport and Exercise, 32, 143-152.

Karamousalidis, G., Galazoulas, C., Mousaridou, E., Bebetsos, E., Grammatikopoulou, M., \& Alexaki, A. (2010). Relation of coaching behavior and role ambiguity. Journal of Physical Education \& Sport/Citius Altius Fortius, 28(3), 45-50.

Kasuba, M. (2018). Az edző-sportoló kapcsolat egy labdarúgó akadémián. Educatio, 27(1), 121-128.

Kelley, H. H., \& Thibaut, J.W. (1978). Interpersonal relations: A theory of interdependence. New York: Wiley

Kenow, L. J., \& Williams, J. M. (1992). Relationship between anxiety, self-confidence, and evaluation of coaching behaviors. The Sport Psychologist, 6(4), 344-357.

Kenow, L. J., \& Williams, J. M. (1993). Factor structure of the coaching behavior questionnaire and its relationship to anxiety and self-confidence. Journal of Sport and Exercise Psychology, 15(4), 377-396.

Kenow, L., \& Williams, J. M. (1999). Coach-athlete compatibility and athlete's perception of coaching behaviors. Journal of Sport Behaviour, 22(2), 251-259.

Kiss, Z., Fózer-Selmeci, B., Csáki, I., \& Bognár, J. (2015). Bentlakó labdarúgó-korosztályok pszichés-mentális jellemzői, Mentálhigiéné és Pszichoszomatika, 16(4), 331-347.

Kovács, K., F. Földi, R., \& Gyömbér, N. (2021). Az Edző-Sportoló Kapcsolat Kérdőív hazai adaptációja, a sportoló szemszögén keresztül. Magyar Sporttudományi Szemle, 22(90), 12-20.

Kovács, K., Gyömbér, N., F. Földi, R., \& Lénárt, Á. (2020). Észlelt autonómia támogatás kérdőívek hazai adaptációja, Alkalmazott Pszichológia 20(1), 103-119.

Kovács, K., Gyömbér, N., Kelemen, Á., \& Földi, R. F. (2019). Az észlelt autonómiatámogatás hatása a teljesítéscélokra karate utánpótláskorosztályoknál. Magyar Pszichológiai Szemle, 74(2), 163-180.

Lafrenière, M. A. K., Jowett, S., Vallerand, R. J., \& Carbonneau, N. (2011). Passion for coaching and the quality of the coach-athlete relationship: The mediating role of coaching behaviors. Psychology of Sport and Exercise, 12(2), 144-152.

Ledochowski, L., Unterrainer, C., Ruedl, G., Schnitzer, M., \& Kopp, M. (2012). Quality of life, coach behaviour and competitive anxiety in Winter Youth Olympic Games participants. British Journal of Sports Medicine, 46(15), 1044-1047.

Lee, H.W., Magnusen, M. J., \& Cho, S. (2013). Strength coach-athlete compatibility: Roles of coaching behaviors and athlete gender. International Journal of Applied Sports Sciences, 25(1), 55-67.

Mageau, G. A., \& Vallerand, R. J. (2003). The coach-athlete relationship: A motivational model. Journal of Sports Science, 21(11), 883-904.

Mavridis, G., Rokka, S., Filippou, F., Mavridis, K., Masadis, G., \& Bebetsos, E. (2019). Investigating the coaching behavior and basic psychological needs among junior basketball players. Conference paper: International Scientific Congress "Applied Sports Sciences" and The Balkan Scientific Congress "Physical Education, Sports, Health". Letöltve: 2021. 11. 13-án: https:/ / www.researchgate.net/publication/341354042_ Investigating_the_Coaching_behavior_and_Basic_Psychological_Needs_among_Junior_Basketball_players/citations

Paic, R., Kajos, A., Meszler, B., \& Prisztóka, Gy. (2018). A Magyar nyelvú sportmotivációs skála (H-SMS) validációja és eredményei, Magyar Pszichológiai Szemle, 73(2), 159-182.

Pelletier, L. G., Rocchi, M. A., Vallerand, R. J., Deci, E. L., \& Ryan, R. M. (2013). Validation of the revised Sport Motivation Scale (SMS-II). Psychology of Sport and Exercise, 14(3), 329-341. 
Révész, L., Bognár, J., Csáki, I., \& Trzaskoma-Bicsérdy, G. (2013). Az edző-sportoló kapcsolat vizsgálata az úszás sportágban. Magyar Pedagógia, 113(1), 53-72.

Sarı, İ., \& Bayazıt, B. (2017). The relationship between perceived coaching behaviours, motivation and self-efficacy in wrestlers. Journal of Human Kinetics, 57(1), 239-251.

Shanmugam, V., Jowett, S., \& Meyer, C. (2012). Eating psychopathology amongst athletes: Links to current attachment styles. Eating Behaviors, 13(1), 5-12.

Sipos, K., Bejek, K., \& Kudar, K. (1999). A magyar nyelvú CSAI-2 versenyszorongás skála sztenderdizálása. In: Mónus A. (szerk.) III. Országos Sporttudományi Kongresszus, II. kötet (293-299). Budapest: Magyar Sporttudományi Társaság

Smith, R.E., Smoll, F. L., \& Hunt, E. (1977). A system for the behavioral assessment of athletic coaches. Research Quarterly. American Alliance for Health, Physical Education and Recreation, 48(2), 401-407.

Smohai, M., Szemes, Á., Bernhardt-Torma, N., Mirnics, Zs., Bóna, K., Kovács, K., et al. (kézirat). A Sportmotivációs Kérdőív (SMS-II) magyar változatának pszichometriai jellemzői.

Smoll, F. L., \& Smith, R. E. (1989). Leadership behaviors in sport: A theoretical model and research paradigm 1. Journal of Applied Social Psychology, 19(18), 1522-1551.

Solomon, G. (2008). Expectations and perceptions as predictors of coaches' feedback in three competitive contexts. Journal for the Study of Sports and Athletes in Education, 2(2), 161-179.

Taber, K. S. (2018). The use of Cronbach's alpha when developing and reporting research instruments in science education. Research in Science Education, 48(6), 1273-1296.

Williams, J. M., Kenow, L. J., Jerome, G. J., Rogers, T., Sartain, T. A., \& Darland, G. (2003). Factor structure of the coaching behavior questionnaire and its relationship to athlete variables. The Sport Psychologist, 17(1), 16-34.

Yang, S. X., Jowett, S., \& Chan, D. K. C. (2015). Effects of big-five personality traits on the quality of relationship and satisfaction in Chinese coach-athlete dyads. Scandinavian Journal of Medicine E Science in Sports, 25(4), 568-580.

Zourbanos, N., Hatzigeorgiadis, A., Tsiakaras, N., Chroni, S., \& Theodorakis, Y. (2010). A multimethod examination of the relationship between coaching behavior and athletes' inherent self-talk. Journal of Sport and Exercise Psychology, 32(6), 764-785.

\section{Köszönetnyilvánítás}

Az Innovációs és Technológiai Minisztérium ÚNKP-20-3 kódszámú Új Nemzeti Kiválóság Programjának a Nemzeti, Kutatási, Fejlesztési és Innovációs Alapból finanszírozott szakmai támogatásával készült.

\section{A szerzók munkamegosztása}

A kutatás szakmai és operatív vezetőjeként az elméleti háttér, az adatok statisztikai elemzése, és a kézirat szövegezése Kovács Krisztina munkája. Az elméleti háttér kidolgozásában és a méróeszköz fordításában való segédkezés, valamint az adatok értelmezése és a kézirat végső szövegezése Gyömbér Noémi munkájához tartozik. A hipotézisek megfogalmazásában és végső szöveg ellenőrzésében F. Földi Rita és Kőnig-Görögh Dóra vettek részt. 


\section{Nyilatkozat érdekütközésról}

A szerzők ezúton kijelentik, hogy esetükben nem állnak fenn érdekütközések.

\section{Hungarian adaptation of the Coach Behaviour Questionnaire KOVÁCS, KRISZTINA - KÖNIG-GÖRÖGH, DÓRA - F. FÖLDI, RITA - GYÖMBÉR, NOÉMI}

Background and aims: The purpose of the study was to examine the psychometric properties of the Hungarian version of the Coaching Behaviour Questionnaire and examine the reliability and validity of this questionnaire. Methods: 432 athletes were involved in this study (mean age $=19.49 ; \mathrm{SD}=5.05 ;$ men $=234$; women $=256$ ). Besides the above-mentioned questionnaire, the Sport Climate Questionnaire, the Sport Motivation Scale-2, the CoachAthlete Relationship Questionnaire, and the Competitive State Anxiety Inventory-2 were applied for the validation. Results: The confirmatory factor analysis supported the twodimensional theoretical model $\left(\chi^{2}=386.36 ; d f=89\right.$; TLI $=0.90 ; \mathrm{CFI}=0.91$; $\mathrm{RMSEA}=0.08$ $[90 \% \mathrm{CI}=0.07-0.09]$; SRMR $=0.07)$, that indicated an acceptable fit to the data. Internal consistency of the subscales (Negative activation Cronbach's $\alpha=0.87$, Supportiveness Cronbach's $\alpha=0.87$ ) proved to be adequate. Examination of construct validity revealed positive relationships among Supportiveness subscale and self-determined motivation, autonomy-supported coach behaviour, self-confidence and coach-athlete relationship $(r=$ $-0.29-0.70)$, and negative relationship among the Negative activation and the trait anxiety in addition to the below mentioned scales $(r=0.21-0.25)$. Discussion: The Hungarian version of the $\mathrm{CBQ}$ seems to be a valid and reliable questionnaire to measure.

Keywords: athlete-coach relationship, coaching behaviour, supportiveness, negative activation

\section{Függelék: Edzői Viselkedés Kérdőív (CBQ-H)}

Instrukció/Kitöltési útmutató: Az alábbiakban olyan kijelentéseket olvashat, amelyekkel a sportolók szokták jellemezni azokat a tényezőket, amelyek hozzájárulnak a versenyen nyújtott teljesítményükhöz.

Kérjük, olvassa el a következő állításokat és mindegyik kapcsán ítélje meg, hogy mennyire igaz az adott állítás. Fontos, hogy a kitöltés közben egy, az Ön számára fontos versenyre gondoljon! Ne gondolkozzon túl sokat, ne időzzön el sokáig az állításoknál!

1 = Egyáltalán nem értek egyet.

2 = Nem értek egyet.

3 = Egyetértek.

4 = Teljes mértékben egyetértek. 


\begin{tabular}{|l|c|c|c|c|}
\hline Az edzőm a kritikát épító jelleggel fogalmazza meg. & 1 & 2 & 3 & 4 \\
\hline Az edzőm verseny alatti viselkedése feszültté és idegessé tesz. & 1 & 2 & 3 & 4 \\
\hline $\begin{array}{l}\text { Amikor szükségem van rá, az edzóm hangszíne megnyugtató és } \\
\text { biztató. }\end{array}$ & 1 & 2 & 3 & 4 \\
\hline Az edzőm kellőképpen higgadt és nyugodt. & 1 & 2 & 3 & 4 \\
\hline $\begin{array}{l}\text { Az edzőm sajátos modora és érzelemkifejezési módja hozzájárul } \\
\text { ahhoz, hogy gyengén teljesítsek. }\end{array}$ & 1 & 2 & 3 & 4 \\
\hline Az edzőm akkor is támogat engem, amikor hibát vétek. & 1 & 2 & 3 & 4 \\
\hline $\begin{array}{l}\text { Idókérésnél és félidóben az edzőm arra helyezi a hangsúlyt, } \\
\text { hogy mit kell csinálnom egy adott helyzetben, nem arra, hogy } \\
\text { mit nem sikerült megvalósítanom. }\end{array}$ & 1 & 2 & 3 & 4 \\
\hline $\begin{array}{l}\text { Az edzőm sajátos modora és érzelemkifejezési módja segít } \\
\text { ellazulnom és jobban teljesítenem. }\end{array}$ & 1 & 2 & 3 & 4 \\
\hline $\begin{array}{l}\text { Az edzőm oldalvonal melletti viselkedése megzavarja a } \\
\text { figyelmemet verseny közben. }\end{array}$ & 1 & 2 & 3 & 4 \\
\hline $\begin{array}{l}\text { Az edzőm az idókéréseket és a félidóket arra használja, hogy } \\
\text { megerósítse az önbizalmamat/önbizalmunkat. }\end{array}$ & 1 & 2 & 3 & 4 \\
\hline Az edzőm kontrollálja az érzelmeit verseny közben. & 1 & 2 & 3 & 4 \\
\hline Amikor az edzóm feszültnek túnik, nem tudok jól teljesíteni. & 1 & 2 & 3 & 4 \\
\hline $\begin{array}{l}\text { Az edzőm verseny alatti viselkedése elbizonytalanít a } \\
\text { teljesítményemmel kapcsolatban. }\end{array}$ & 1 & 2 & 3 & 4 \\
\hline $\begin{array}{l}\text { Idegesebb leszek az oldalvonalon álló edzőm látványától, mint } \\
\text { magától a versenytól. }\end{array}$ & 1 & 2 & 3 & 4 \\
\hline Az edzőm feszültséget kelt bennem. & 1 & 2 & 3 & 4 \\
\hline
\end{tabular}

\section{Skálaképzési útmutató:}

A kérdőívben nem található fordított item.

Az alskálaképzés a hozzájuk tartozó tételek összeadásával történik.

Negatív reakció alskála: 2., 5., 9., 12., 13., 14. és 15. tétel.

Támogatás alskála: 1., 3., 4., 6., 7., 8., 10. és 11. tétel.

A cikk a Creative Commons Attribution 4.0 International License (https:/ / creativecommons.org/ licenses/by/4.0/) feltételei szerint publikált Open Access közlemény, melynek szellemében a cikk bármilyen médiumban szabadon felhasználható, megosztható és újraközölhető, feltéve, hogy az eredeti szerző és a közlés helye, illetve a CC License linkje és az esetlegesen végrehajtott módosítások feltüntetésre kerülnek. (SID_1) 